\title{
How Survey Design Affects Monkey Counts: A Case Study on Individually Recognized Spider Monkeys (Ateles geoffroyi)
}

\author{
Denise Spaan $^{\mathrm{a}, \mathrm{b}} \quad$ Gabriel Ramos-Fernández ${ }^{\mathrm{b}-\mathrm{d}}$ \\ Colleen M. Schaffner ${ }^{a, b}$ Braulio Pinacho-Guendulain ${ }^{c, e}$ \\ Filippo Aureli ${ }^{a}, b, f$ \\ ${ }^{a}$ Instituto de Neuroetología, Universidad Veracruzana, Xalapa, ${ }^{b}$ ConMonoMaya A.C., \\ Chemax, 'Centro Interdisciplinario de Investigación para el Desarrollo Integral Regional, \\ Unidad Oaxaca, Instituto Politécnico Nacional, Oaxaca, ${ }^{\mathrm{d} C e n t r o}$ de Ciencias de la \\ Complejidad, Universidad Nacional Autónoma de Mexico, Mexico City, and \\ e Conservación de la Biodiversidad del Usumacinta A.C., Emiliano Zapata, Mexico; \\ ${ }^{f}$ Research Centre in Evolutionary Anthropology and Palaeoecology, Liverpool John Moores \\ University, Liverpool, UK
}

\begin{abstract}
Keywords
Population monitoring · Fission-fusion dynamics · Missing individuals · Ateles geoffroyi
\end{abstract}

\begin{abstract}
The fast movement and high degree of fission-fusion dynamics of spider monkeys (Ateles spp.) make them notoriously difficult to survey. We examined which aspects of survey design affect spider monkey sightings along transects in a group of individually recognized spider monkeys (Ateles geoffroyi) in Punta Laguna, Yucatan, Mexico. We calculated the number of monkeys and subgroups sighted per transect walk. Using generalized linear models, we found no effect of the number of observers, transect type (new vs. existing), walking speed, or time of day on individual monkey counts or subgroup counts. Recounting of individuals was relatively rare and occurred when transects were walked relatively slowly. We missed more young than adult monkeys. The group composition based on survey data was similar to the known group composition. Based on our findings we recommend that surveys performed on relatively flat terrain be conducted at speeds similar to or faster than the moving speed of spider monkeys to minimize recounting of individuals and that young:adult female ratios based on survey data be interpreted as conservative indicators of population health. The novel methods presented to determine sources of bias in population estimates are applicable to a wide range of primates that are difficult to survey.

(c) 2017 S. Karger AG, Basel
\end{abstract}

\begin{tabular}{|c|c|c|}
\hline KARGER & (C) 2017 S. Karger AG, Basel & $\begin{array}{l}\text { Denise Spaan } \\
\text { Instituto de Neuroetología. Universidad Veracruzana }\end{array}$ \\
\hline $\begin{array}{l}\text { E-Mail karger@karger.com } \\
\text { www.karger.com/fpr }\end{array}$ & & $\begin{array}{l}\text { Av. Dr. Luis Castelazo s/n, Col. Industrial Animas } \\
\text { Xalapa, Veracruz } 91190 \text { (Mexico) } \\
\text { E-Mail denisespaan@ hotmail.com }\end{array}$ \\
\hline
\end{tabular}




\section{Introduction}

Line transect surveys are the most commonly used method to survey arboreal primates [Peres, 1999; Buckland et al., 2010a, b], providing population density estimates (e.g., individuals per $\mathrm{km}^{2}$ ) or encounter rates (e.g., individuals per $\mathrm{km}$ ), which form the base of a wide variety of studies in ecology and conservation and aid in the formulation of species management plans. The number of monkeys sighted may be affected by survey design, which in turn may affect population density estimates or encounter rates.

Survey design is often limited by field conditions, but only a handful of studies have investigated how survey design affects primate population estimates. Firstly, primate surveys are commonly performed in the morning and late afternoon [Peres, 1999; Ingberman et al., 2009] as primates are more likely to be encountered during periods of heightened activity [Chapman et al., 1988; Peres, 1999], yet there is no general trend on how time of day affects encounter rate or population density [Ingberman et al., 2009; Kun-Rodrigues et al., 2013; Lee et al., 2014; Matsuda et al., 2016]. For instance, early morning is the optimum time to survey gibbons [Hylobates agilis; Lee et al., 2014], whereas time of day did not affect either howler monkey (Alouatta clamitans) or sifaka (Propithecus coquereli) population estimates [Ingberman et al., 2009; Kun-Rodrigues et al., 2013]. Secondly, the effects of survey speed on encounter rate remain poorly investigated [Shupe et al., 1987; Iwanaga and Ferrari, 2002; AliagaRossel et al., 2006; Nekaris et al., 2014] despite its importance to detectability. Thirdly, line transect surveys are typically performed by a group of 1-2 observers. Studies examining the effect of the number of observers on encounter rate or population density estimates are limited and suggest that the number of observers does not affect the primate encounter rate [Nijman and Menken, 2005; Haus et al., 2009].

Understanding how study design affects encounter rates may be especially important for species that are difficult to survey (often providing low encounter rates), such as those with high degrees of fission-fusion dynamics (i.e., a high temporal variation in the degree of spatial cohesion and individual membership in subgroups) [Aureli et al., 2008] and fast arboreal movement, such as spider monkeys [Ateles spp.; Symington, 1990; Chapman et al., 1995]. These characteristics make it problematic to meet at least 2 of the assumptions of line transect surveys [Buckland et al., 2001, 2010a, b; Ross and Reeve, 2011]: (1) groups or individuals are detected before they respond to the observer by fleeing, and the non-responsive speed (i.e., a movement which is independent of the observer's presence) of the animal is slower than the observer's speed; and (2) group sizes are recorded precisely and groups are not counted twice.

Violating the assumptions of line transect surveys could lead to inaccurate population estimates. Fast movement enables spider monkeys to flee out of the observer's sight before they are detected. Walking at a speed that is faster than the commonly used $1 \mathrm{~km} / \mathrm{h}$ may counter the problem of non-responsive movement [Plumptre et al., 2013], as the observer's speed is closer to the study species' speed. Although it has been suggested that subgroup size can be measured instead of group size for species with high degrees of fission-fusion dynamics [Peres, 1999], subgroup size changes in relation to fruit availability [Chapman et al., 1995; Pinacho-Guendulain and RamosFernández, 2017] and the average subgroup size differs between seasons [Hashimoto et al., 2003; Asensio et al., 2009], whereas group size remains the same. It is difficult 
to ensure that the same group, subgroup or individuals are not counted multiple times. Despite this potentially common violation, to date no primate studies have aimed to investigate how often the same individual or group is detected at various points on the same transect during the same transect walk.

Our study aimed to examine which aspects of survey design affect spider monkey sightings along transects and determine whether 2 relevant assumptions of line transect sampling are violated. To do so, we surveyed a group of individually recognized spider monkeys. We use the findings to provide recommendations for the design of surveys for animals exhibiting fast movement and high degrees of fission-fusion dynamics.

\section{Method}

Study Site and Subjects

We collected data between October 2014 and January 2015 in the Otoch Ma'ax yetel Kooh Flora and Fauna Protected Area $\left(20^{\circ} 38^{\prime}\right.$ N, $87^{\circ} 38^{\prime}$ W, $14 \mathrm{~m}$ above sea level; Fig. 1) near the village of Punta Laguna, Yucatan, Mexico. Geoffroy's spider monkeys (Ateles geoffroyi) have been continuously studied in the protected area over the past 20 years [Ramos-Fernández et al., in press]. The study group included 36 individually identifiable monkeys older than 1 year: 4 adult males, 1 subadult male, 12 adult females, 5 subadult females, and 14 young. We defined young as individuals younger than 5 years but older than 1 year, given that infants aged less than 1 year still cling to their mothers' bodies for large periods of time and individuals younger than 5 years are found in the same subgroup as their mother [Vick, 2008]. Subadults were individuals between 5 and 8 years old, being sexually mature but not fully grown, and adults were individuals older than 8 years [Shimooka et al., 2008]. Females can be easily distinguished from adult males based on the presence of a protruding clitoris. The group included 11 mother-young dyads based on continuously updated demographic records.

We used an existing transect and a newly cut transect of the same length (919 m; Table 1). To increase the likelihood of monkey sightings we selected the existing transect from the trail system as spider monkeys used the area around the selected trail during the same period the previous year. We opened the newly cut transect roughly parallel to the existing transect (Fig. 1). Both transects were located on relatively flat terrain with only a few large boulders.

\section{Survey Design}

We performed surveys according to the line transect method [Peres, 1999]. We walked transects at a speed of $1.0-2.0 \mathrm{~km} / \mathrm{h}$ visually scanning all levels of vegetation and listening for spider monkeys. We performed surveys twice daily for most survey days, without walking the same transect more than 3 times per day. We did not consider multiple walks per day on the same transect to be problematic because 2 walks of the same transect are considered independent if separated by a few hours [Peres, 1999]; this would not be appropriate for slower moving primates. Additionally, the spider monkeys in our study group have large daily traveling distances [1.18$3.87 \mathrm{~km}$; Ramos-Fernández and Ayala-Orozco, 2003]. The first author was an observer in all surveys. Transect walks were performed by 1,2 , or 3 observers and in 1 of 3 time blocks covering all hours of the day in which spider monkeys were active (Table 1).

\section{Data Collection}

During each survey we collected the following data: start and end time, date of survey, and number of observers, and we noted whether the transect was newly cut or existing. When monkeys were sighted during line transect surveys, we spent no more than 10 min collecting data on subgroup size, composition, time of sighting, and location (using a handheld GPS device).

We collected data on subgroup composition by categorizing independently moving monkeys into 2 age classes: adult and young. Adults were distinguished from young based on the size 


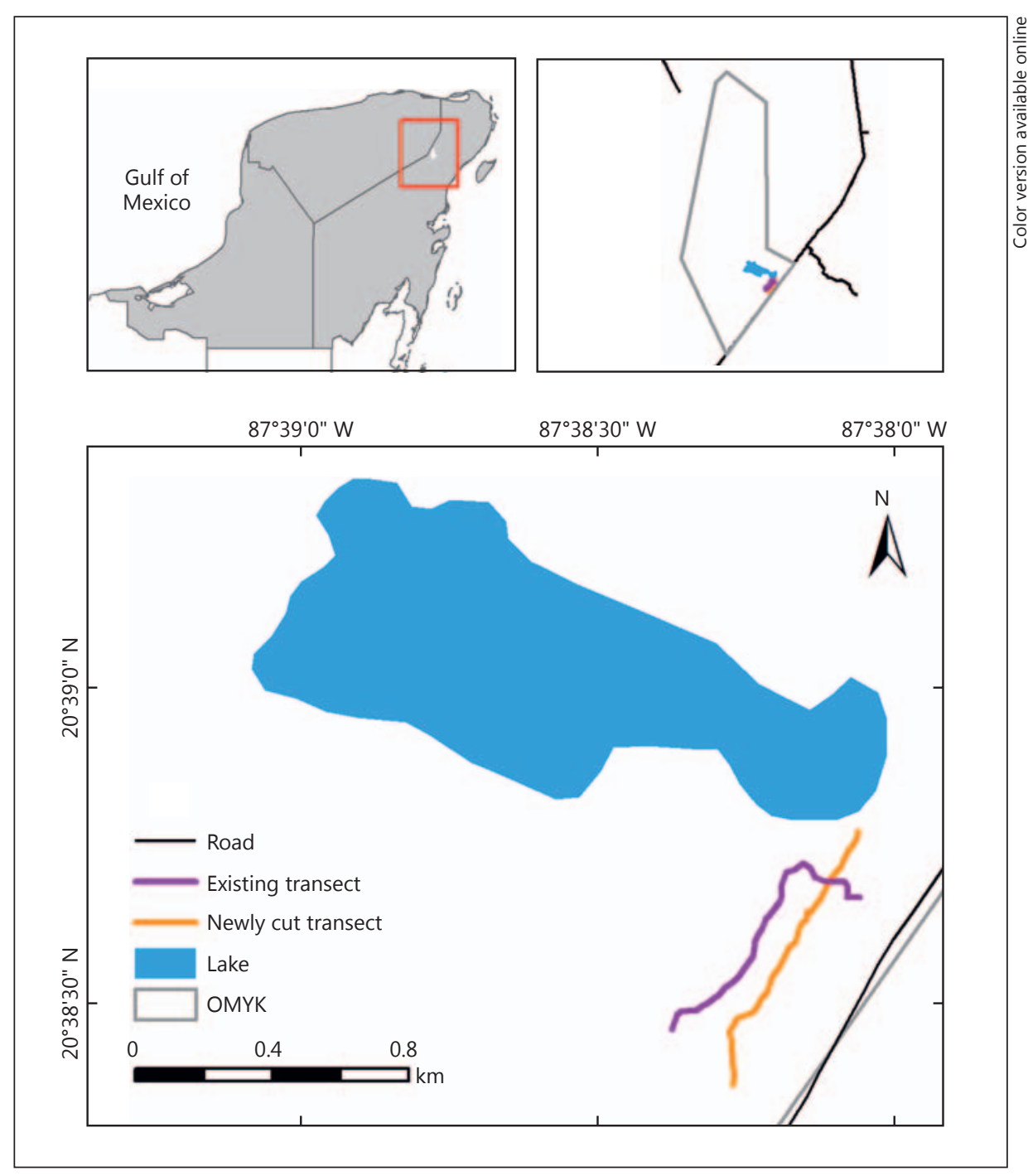

Fig. 1. Location of the 2 line transects for the study site in the Otoch Ma'ax yetel Kooh (OMYK) Flora and Fauna Protected Area.

of the individual and facial coloration [Vick, 2008]. We included subadult individuals in the adult class as they are difficult to distinguish from adults during surveys. We excluded infants clinging to their mothers from the analyses as they may often be obscured from view.

During 2- and 3-observer transect walks, spider monkeys were individually recognized by trained field assistants (with 20 years of experience in identifying spider monkeys) and the identity of all sighted monkeys was recorded. We assigned each sighted individual to its age class based on its identity. This was possible since subgroups included on average (mean \pm SE) $2.7 \pm$ 0.17 independently moving individuals; this would not be possible for species that move in larger groups. 
Table 1. Number of walks performed on each transect in relation to the number of observers and time block

\begin{tabular}{|c|c|c|c|c|c|c|c|c|}
\hline \multirow{2}{*}{$\begin{array}{l}\text { Transect } \\
\text { type }\end{array}$} & \multirow{2}{*}{$\begin{array}{l}\text { Transect } \\
\text { length, } \\
\text { km }\end{array}$} & \multicolumn{3}{|c|}{ Number of observers } & \multicolumn{3}{|c|}{ Time block } & \multirow[b]{2}{*}{ Total } \\
\hline & & 1 & 2 & 3 & $\begin{array}{l}06: 00 \\
-10: 00\end{array}$ & $\begin{array}{l}10: 01 \\
-14: 00\end{array}$ & $\begin{array}{l}14: 01 \\
-18: 00\end{array}$ & \\
\hline Newly cut & 0.919 & $8(40)$ & $35(75)$ & $7(11)$ & $23(84)$ & $18(16)$ & $9(26)$ & $50(126)$ \\
\hline Existing & 0.919 & $7(3)$ & $37(123)$ & $8(28)$ & $24(45)$ & $16(54)$ & $12(55)$ & $52(154)$ \\
\hline Total & & $15(43)$ & $72(198)$ & $15(39)$ & $47(129)$ & $34(70)$ & $21(81)$ & $102(280)$ \\
\hline
\end{tabular}

The number of sighted monkeys is presented in parentheses.

\section{Data Analyses}

Aspects of Study Design

We ran generalized linear models to determine the effect of the number of observers $(1,2$, or 3), walking speed (continuous from 1.0 to $2.0 \mathrm{~km} / \mathrm{h}$ ), and the time of the day in which the survey was carried out (06:00-10:00, 10:01-14:00, or 14:01-18:00) on individual counts (i.e., number of sighted monkeys) or subgroup counts (i.e., number of sighted subgroups). We ran 2 sets of models with walking speed calculated in different ways. We calculated walking speed including the time to record monkey sightings for one set of models and excluding such recording time for the other set of models. We used variance inflation factor to assess collinearity between predictor variables. All variance inflation factor values were below 2 , indicating that there was no collinearity between predictor variables [Rhodes et al., 2009]. Typically, Poisson distributions are used to model count data [Richards, 2015]. After checking for overdispersion [Buckley, 2015], we modeled individual counts and subgroup counts using negative binomial distributions. We created negative binomial generalized linear models using the glm.nb function of the package MASS [Ripley et al., 2013] in the program R v. 3.2.1 [R Core Team, 2016]. We entered month and transect type (newly cut vs. existing trail) as control variables in all models to account for the potential effect of a different distribution of food sources across months and repeat transect walks on the same transects. We compared the full models to null models including only the control variables (month and transect type) using a likelihood ratio test [Forstmeier and Schielzeth, 2011], with the ANOVA function in R. $p<0.05$ was considered statistically significant.

\section{Assumptions for Line Transect Surveys}

During 2- and 3-observer transect walks, we used the individual identity of the spider monkeys to determine whether individuals were sighted multiple times during the same transect walk (recounted individuals). We calculated the percentage of individuals that were recounted by dividing the total number of recounted individuals by the total number of individuals that were encountered and multiplying this figure by 100 . To determine whether walking speed affects recounting individuals, we divided transect walks into slowly walked when the walking speed was $1.0-1.49 \mathrm{~km} / \mathrm{h}(n=70)$ and rapidly walked when the speed was $1.5-2.0 \mathrm{~km} / \mathrm{h}(n=32)$. We selected these 2 speed categories as previous line transect surveys of spider monkeys have been walked at speeds below or above $1.5 \mathrm{~km} / \mathrm{h}$ [ $>1.5 \mathrm{~km} / \mathrm{h}$ : Cant, 1978; Iwanaga and Ferrari, 2002; Ravetta and Ferrari, 2009; <1.5 km/h: Weghorst, 2007; Link et al., 2010; Aquino et al., 2012; Kolowski and Alonso, 2012; Méndez-Carvajal, 2013].

Given that we knew the demographic composition of the group, in 2- and 3-observer transect walks we could establish when we missed the mother of a sighted young or we missed the young of a sighted mother. We calculated the proportion of missed individuals per transect and age class by dividing the total number of missed individuals by the total number of individuals that should have been present in the encountered subgroups (i.e., all sighted and missed individuals) during all walks of one transect. This analysis was limited to mother-infant dyads as we 
could not determine whether other individuals were missed during surveys. To determine whether more individuals were missed if they were at greater distances from the transect center line, we considered the perpendicular distance from each missed individual as the mean of the perpendicular distances from all sighted members of the same subgroup. We then compared these mean values to the distribution of the corresponding mean values for all sighted subgroups.

Using survey data without taking into account individual identities, we calculated the proportion of adult males, adult females, and young by dividing the number of individuals of each age-sex class by the total number of sighted individuals (i.e., adult males, adult females, and young). We compared proportions obtained from the survey data to the proportions based on the known group composition.

We calculated the young:adult female ratio of individuals distinguishing adult females from young simply based on size and facial markings. We performed this calculation using only individuals observed during 2 - and 3-observer walks as we also calculated the ratio excluding subadult females based on their identity. We compared this ratio to the ratio based on the actual group composition and to ratios including missed young and/or missed adult females.

\section{Results}

In the 102 transect walks (Table 1), for a total survey effort of $93.74 \mathrm{~km}$, we sighted 280 spider monkeys (newly cut transect: 126; existing transect: 154) in 103 subgroups (newly cut transect: 48 ; existing transect: 55$)$. The mean $( \pm \mathrm{SE})$ size of the encountered subgroups was $2.7 \pm 0.17$ (newly cut transect: $2.7 \pm 0.28$, range: $1-12$; existing transect: $2.8 \pm 0.21$, range: $1-6)$. The size distribution for the encountered subgroups during surveys was similar to that for subgroups found by other researchers in the same area during the study period ( $77 \%$ of the encountered subgroups fell within the first and third quartiles of the size distribution of subgroups found by other researchers). The number of sighted spider monkeys during each time block and in relation to the number of observers is presented in Table 1.

Full-null model comparisons found that the predictor variables did not affect individual spider monkey counts including $\left(\chi^{2}=7.06\right.$, d.f. $\left.=5, p=0.22\right)$ or excluding the time to record individuals $\left(\chi^{2}=7.04\right.$, d.f. $\left.=5, p=0.22\right)$. Similarly, the predictor variables did not affect spider monkey subgroup counts including $\left(\chi^{2}=10.69\right.$, d.f. $=$ $5, p=0.06)$ or excluding recording time $\left(\chi^{2}=10.62\right.$, d.f. $\left.=5, p=0.06\right)$.

During 2- and 3-observer transect walks we sighted a total of 237 spider monkeys older than 1 year in 89 subgroups including 115 adult females and 93 young. Recounting of individuals was relatively rare, with only 5 monkeys reencountered during the same transect walks ( 3 on the newly cut transect and 2 on the existing transect), which is $2.1 \%$ of the encountered monkeys in $3.3 \%$ of the encountered subgroups ( 3 of the 89 subgroups) (Table 2). No monkey was recounted more than once. The subgroup composition changed between the first and second sighting (Table 2). The 5 instances of recounting individuals occurred on 3 separate transect walks (Table 2). All 5 cases of recounting occurred when transects were walked slowly (i.e., $1.0-1.49 \mathrm{~km} / \mathrm{h}$ ).

There was no clear effect of walking speed on missing individuals. When we walked transects slowly, 6 individuals were missed ( 2 adult females and 4 young), whereas 9 individuals (all young) were missed when we walked transects fast. A larger number of young were missed than adult females during surveys; 2 adult females ( 1 on each transect) were missed, representing $1.7 \%$ of the encountered adult female monkeys (115 sighted and 2 missed); 13 young (newly cut transect: 7; existing tran- 
Table 2. Age-sex classes of recounted individual spider monkeys during the same transect walk

\begin{tabular}{llllll}
\hline Transect & $\begin{array}{l}\text { Age-sex } \\
\text { class }\end{array}$ & $\begin{array}{l}\text { Time between } \\
\text { sightings, } \\
\text { min }\end{array}$ & $\begin{array}{l}\text { Distance between } \\
\text { sightings } \\
\text { (straight line), m }\end{array}$ & $\begin{array}{l}\text { Subgroup } \\
\text { size (first } \\
\text { sighting) }\end{array}$ & $\begin{array}{l}\text { Subgroup size } \\
\text { (second } \\
\text { sighting) }\end{array}$ \\
\hline New & $\mathrm{AF}^{\mathrm{a}}$ & 12 & 104 & 2 & 4 \\
New & $\mathrm{Y}^{\mathrm{a}}$ & 12 & 104 & 2 & 4 \\
New & $\mathrm{AF}$ & 9 & 100 & 2 & 1 \\
Existing & $\mathrm{Y}^{\mathrm{b}}$ & 9 & 57 & 5 & 2 \\
Existing & $\mathrm{Y}^{\mathrm{b}}$ & 9 & 57 & 5 & 2 \\
\hline
\end{tabular}

AF, adult female, $Y$, young. ${ }^{a}$ These 2 individuals were in the same subgroup. ${ }^{\mathrm{b}}$ These 2 individuals were in the same subgroup.

sect: 6) were missed, representing $12.3 \%$ of the encountered young (93 sighted and 13 missed). The number of individuals missed during surveys did not appear to increase with increasing perpendicular distance from the transect ( $80 \%$ of perpendicular distance means for subgroups with missed individuals fell within the first and third quartiles of the distribution of all subgroup perpendicular distance means).

Using survey data without taking into account individual identities, the proportions of adult males, adult females, and young were $0.10,0.48$, and 0.42 , respectively; whereas the corresponding proportions based on the known group composition were $0.14,0.47$, and 0.39 . The young:adult female ratio for the survey data was 0.81 . When both missed adult females and young were included, the ratio equalled 0.91 . The young:adult female ratio based on the actual group composition (14 young and 12 adult females) was 1.17, but when the 5 subadult females were combined with the 12 adult females the ratio was 0.82 .

\section{Discussion}

We found no effect of time of day, walking speed, or number of observers on individual spider monkey and subgroup counts. Although spider monkey activity peaks in the early morning and late afternoon [Green, 1978; Wallace, 2001], corresponding to peaks in encounter rate [Green, 1978], we found no effect of time of day on spider monkey counts. Similar to our results, spider monkey (A. hybridus) surveys done in forest fragments found no effect of time of day on encounter rate [Marsh et al., 2016]. Previous studies on Atelines (A. chamek and Lagothrix cana) support our findings as walking speed did not affect encounter rate [Iwanaga and Ferrari, 2002].

The spider monkeys inhabiting Otoch Ma'ax yetel Kooh are highly habituated to human presence as ecotourism has been the major source of income in the Punta Laguna village for more than 14 years, and guides enter the forest with small groups of tourists at least once per day. It is therefore likely that the number of observers would not affect spider monkeys' behavior and therefore their sighting along transects at the study site. Surveys of arboreal and terrestrial unhabituated primates, including fast moving gibbons (Hylobates muelleri), found no effect of the number of 
observers on counts [Nijman and Menken, 2005; Haus et al., 2009], suggesting that our results may be applicable to unhabituated groups of spider monkeys, and other primates with fast arboreal movement or high degrees of fission-fusion dynamics.

Otoch Ma'ax yetel Kooh is a highly seasonal environment with marked dry and wet seasons. This study was carried out during the wet season when the canopy cover is at its fullest and detectability is most difficult, a situation as similar as possible to other tropical rainforest environments. It must be noted that the canopy height in the study area is up to around $25 \mathrm{~m}$, lower than other spider monkey habitats [Medellín and Equihua, 1998]. Although a low canopy may enhance detectability, the average height at which spider monkeys (A. belzebuth belzebuth) feed in taller forests [16.6 m; Dew, 2005] is around the same height as the canopy at our study site. Our results should therefore be applicable to spider monkeys living in less seasonal habitats with taller canopies.

The low number of recounted individuals suggests that the fast movement of spider monkeys [mean \pm SE: $1.6 \pm 0.4 \mathrm{~km} / \mathrm{h}$ at the study site; Ramos-Fernández, unpubl. data] does not affect recounting when the observers walk at a comparable speed. The high degree of fission-fusion dynamics may explain why recounted spider monkeys were found in different subgroups between first and second encounters. During surveys of species that form cohesive groups, surveyors may avoid recounting by excluding groups that have the same size and composition as ones previously encountered. Our results show that for species with high degrees of fission-fusion dynamics this approach does not work as subgroup size and composition can change quickly and over short distances (Table 1). This potential problem is likely minimal as we only recounted $2.1 \%$ of the encountered monkeys. All 5 cases of recounting occurred when we walked transects at a speed of $<1.5 \mathrm{~km} / \mathrm{h}$, suggesting that walking slowly may increase the chance of recounting spider monkeys, but this interpretation awaits confirmation given our small sample sizes. To our knowledge this is the first study examining the recounting of individuals and subgroups. The difficulty to ensure that the same group, subgroup, or individuals are not counted multiple times does not apply only to spider monkeys. It would be beneficial if similar studies were performed on other individually identified populations of primates with similar or lower levels of fission-fusion dynamics and movement to understand the potential effect on population surveys. Understanding how quickly the same individuals or subgroups are recounted during surveys can greatly improve survey designs. Repeating transect walks sooner than the time needed to insure independence would result in repeated counts of the same individuals and groups. Our results demonstrate that for spider monkeys the same transect can be walked repeatedly within short time periods. The time required to insure independence of transect walks differs between primate species. The time between walking the same transect is critical for slow-moving species, which may remain on the same transect for days or weeks. For instance, Alouatta palliata move on average $381 \mathrm{~m} /$ day [Garber and Jelinek, 2006].

More young went undetected during surveys than adult females. The proportion of adult females that went undetected during surveys was low (1.7\%). Given that male spider monkeys tend to move faster than females [Shimooka, 2005], we cannot assume that a similar proportion of males may have been missed, despite the lack of sexual dimorphism in spider monkeys [Rosenberger et al., 2008]. Based on this consideration and the actual number of adult females and young that were missed, it is possible that more than $10 \%$ of individuals over the age of 1 year went undetected

416
Folia Primatol 2017;88:409-420 DOI: $10.1159 / 000481796$
Spaan/Ramos-Fernández/Schaffner/ Pinacho-Guendulain/Aureli 
during surveys, thereby potentially violating the assumption that groups are counted accurately. It is therefore vital to report sources of error and confidence intervals of population density estimates and encounter rates.

Surveyors often collect data on group composition, but little evidence exists as to whether these proportions reflect the actual group composition. The proportion of adult females and young were similar between the survey data without using individual identities (0.48 and 0.42 ) and the actual group composition (0.47 and 0.39 ), suggesting that surveys are reliable sources of information of group composition for these age-sex classes. These proportions fell within those of adult females and young reported for other spider monkey populations [adult females: $0.33-0.52$, young: $0.20-$ 0.45 ; Shimooka et al., 2008]. The proportion of adult males was only slightly lower using the survey data (0.10) than the actual group composition (0.14). Both proportions are on the lower end of those recorded for spider monkey populations (0.14$0.36)$ and lower than other populations of A. geoffroyi $(0.2-0.26)$. These results confirm that group composition data collected during surveys are reliable. This is particularly important for studies that compare group composition in different areas, for instance areas undergoing different anthropogenic threats.

Surveys are often performed in unexplored areas and may aim to provide information on population health using the young:adult female ratio [Fedigan and Jack, 2001]. All of the ratios we calculated to evaluate the issues of missing individuals and misclassifying subadult females during surveys fell within the young:adult female ratios of other spider monkey populations [0.36-1.31; Shimooka et al., 2008]. The young:adult female ratio obtained from the survey data, in which we did not distinguish subadult females from adult females, was 0.81 . When we added the number of subadult females to the actual number of adult females in the group the ratio was 0.82 , showing a high accuracy of estimates based on survey data. Missing young disproportionally relative to adult females during surveys (12.3 vs. $1.7 \%$ ) can negatively bias the young:adult ratio. The ratio obtained from our survey data (0.81) was lower than the ratio when missed individuals were included (0.91). Based on the underestimated young:adult female ratio the population would appear less healthy than it actually is, although this is arguably preferable to overestimating the ratio, in terms of the consequences for conservation. Distinguishing nulliparous subadult females from adult females during population surveys may be problematic due to their similar size and thus several studies did not distinguish between subadult and adult females [Struhsaker, 1981; Fedigan and Jack, 2001; Treves, 2001]. As subadult females have yet to contribute reproductively to the population, their inclusion in the adult female age class negatively biases the young:adult female ratio. In our study, the young:adult female ratio obtained from the survey data (0.81), in which subadult females were likely included as adult females, was lower than the ratio based on only the actual number of adult females in the group during the study period (1.17), which would again suggest that the population is less healthy than it actually is. We therefore advise that ratios based on survey data be interpreted as conservative indicators of population health. For species in which subadult females can be clearly distinguished from adult females during surveys, biases may be reduced.

There is an increasing need to standardize survey techniques so that population estimates of the same species can be compared across its range. Our results show that aspects of survey design do not affect spider monkey counts, suggesting that surveys can be successfully adapted to the logistical constraints of the survey site. Addition- 
ally, our study provided the first evidence that recounting of individuals during the same transect walk was relatively rare and that young were missed more often than adult females. We recommend that similar studies be performed on individually identifiable primate populations to understand potential sources of bias in population estimates and young:adult female ratios. Based on our findings, we recommend that surveys performed in relatively flat terrain be conducted at a speed similar or faster than the moving speed of spider monkeys to minimize recounting of individuals. Our research contributes to improving and standardizing line transect survey methods for spider monkeys and other species with fast arboreal movement and/or a high degree of fission-fusion dynamics. Many primates living in dense tropical forests are difficult to survey because they live in large, widely dispersed groups (e.g., red colobus, long-tailed macaques, uakaris) in which multiple individuals may be obscured from view or may flee before detection due to their fast movement. The novel methods presented in this article evaluating recounting, missing individuals, subgroup composition, and young:adult female ratios are applicable to a wide range of primate species that are difficult to survey and for which it is particularly important to determine potential sources of bias.

\section{Acknowledgments}

We would like to thank our field assistants Anthony Denice, Augusto Canul, Eulogio Canul, Macedonio Canul, and Juan Canul for assistance with data collection. We would also like to thank the Consejo Nacional de Ciencia y Tecnología (CONACYT: CVU: 637705), Chester Zoo, the Comisión Nacional de Áreas Naturales Protegidas (CONANP) (PROCER/DRPYyCM/2/2015), the Instituto Politécnico Nacional, and the Instituto de Neuroetología of the Universidad Veracruzana for financial and logistical support. Research complied with protocols approved by the Secretaría del Medio Ambiente y Recursos Naturales (SEMARNAT: SGPA/DGVS/02716/14 and SGPA/DGVS/10405/15) and adhered to the legal requirements of Mexico. The CONANP gave us permission to conduct surveys in the protected area. We kindly thank Martha Bonilla-Moheno and Jorge Morales-Mavil, 3 anonymous reviewers and the editor for invaluable comments which greatly improved this paper.

\section{Disclosure Statement}

The authors have no conflicts of interest to declare.

\section{References}

Aliaga-Rossel ER, Mcguire TL, Hamilton H (2006). Distribution and encounter rates of the river dolphin (Inia geoffrensis boliviensis) in the central Bolivian Amazon. Journal of Cetacean Research and Management 8: 87-92.

Aquino R, Cornejo FM, Pezo E, Heymann EW (2012). Distribution and abundance of white-fronted spider monkeys, Ateles belzebuth (Atelidae), and threats to their survival in Peruvian Amazonia. Folia Primatologica 84: 1-10.

Asensio N, Korstjens A, Aureli F (2009). Fissioning minimizes ranging costs in spider monkeys: a multilevel approach. Behavioural Ecology and Sociobiology 63: 649-659.

Aureli F, Schaffner CM, Boesch C, Simon K, Call J, Chapman, CA, Connor R, Di Fiore A, Dunbar RIM, Henzi SP, Holecamp K, Korstjens AH, Layton R, Lee P, Lehmann J, Manson JH, Ramos-Fernández G, Strier K, van Schaik CP (2008). Fission-fusion dynamics new research frameworks. Current Anthropology 49: 627-654. 
Buckland ST, Anderson DR, Burnham KP, Laake JL, Borchers DL, Thomas L (2001). Introduction to Distance Sampling: Estimating Abundance of Biological Populations. Oxford, Oxford University Press.

Buckland ST, Plumptre AJ, Thomas L, Rexstad EA (2010a). Line transect sampling of primates: can animal-to-observer distance methods work? International Journal of Primatology 31: 485-499.

Buckland ST, Plumptre AJ, Thomas L, Rexstad EA (2010b). Design and analysis of line transect surveys for primates. International Journal of Primatology 31: 833-847.

Buckley YM (2015). Generalized linear models. In Ecological Statistics: Contemporary Theory and Application (Fox G, Negrete-Yankelevich S, Sosa VJ, eds.), pp 131-147. Oxford, Oxford University Press.

Cant JGH (1978). Population survey of the spider monkey Ateles geoffroyi at Tikal, Guatemala. Primates 19: 525-535.

Chapman CA, Fedigan LM, Fedigan L (1988). A comparison of transect methods of estimating population densities of Costa Rican primates. Brenesia 30: 67-80.

Chapman CA, Wrangham RW, Chapman LJ (1995). Ecological constraints on group size: an analysis of spider monkey and chimpanzee subgroups. Behavioral Ecology and Sociobiology 36: 59-70.

Dew JL (2005). Foraging, food choice, and food processing by sympatric ripe-fruit specialists: Lagothrix lagotricha peoppigii and Ateles belzebuth belzebuth. International Journal of Primatology 26: 11071135.

Fedigan LM, Jack K (2001). Neotropical primates in a regenerating Costa Rican dry forest: a comparison of howler and capuchin population patterns. International Journal of Primatology 22: 689-713.

Forstmeier W, Schielzeth H (2011). Cryptic multiple hypotheses testing in linear models: overestimated effect sizes and the winner's curse. Behavioral Ecology and Sociobiology 65: 47-55.

Garber PA, Jelinek PE (2006). Travel patterns and spatial mapping in Nicaraguan mantled howler monkeys (Aloutta palliata). In New Perspectives in the Study of Mesoamerican Primates: Distribution, Ecology, Behavior, and Conservation (Estrada A, Garber PA, Pavelka MSM, Leuke L, eds.), pp 287309. New York, Springer.

Green KM (1978). Primate censusing in northern Colombia: a comparison of two techniques. Primates 19: 537-550.

Hashimoto C, Suzuki S, Takenoshita Y, Yamagiwa J, Basabose AK, Furuichi T (2003). How fruit abundance affects the chimpanzee party size: a comparison between four study sites. Primates $44: 77-81$.

Haus T, Vogt M, Forster B, Vu NT, Ziegler T (2009). Distribution and population densities of diurnal primates in the Karst forests of Phong Nha-Ke Bang National Park, Quang Binh Province, central Vietnam. International Journal of Primatology 30: 301-312.

Ingberman B, Fusco-Costa R, de Araujo Monteiro-Filho EL (2009). Population survey and demographic features of a coastal island population of Alouatta clamitans in Atlantic forest, southeastern Brazil. International Journal of Primatology 30: 1-14.

Iwanaga S, Ferrari SF (2002). Geographic distribution and abundance of woolly (Lagothrix cana) and spider (Ateles chamek) monkeys in southwestern Brazilian Amazonia. American Journal of Primatology 56: 57-64.

Kolowski JM, Alonso A (2012). Primate abundance in an unhunted region of the northern Peruvian Amazon and the influence of seismic oil exploration. International Journal of Primatology 33: 958-971.

Kun-Rodrigues C, Salmona J, Besolo A, Rasolondraibe E, Rabarivola C, Marques TA, Chikhi L (2013). New density estimates of a threatened sifaka species (Propithecus coquereli) in Ankarafantsika National Park. American Journal of Primatology 76: 515-28.

Lee DC, Powell VJ, Lindsell JA (2014). The conservation value of degraded forests for agile gibbons $\mathrm{Hylo}$ bates agilis. American Journal of Primatology 77: 76-85.

Link A, de Luna AG, Alfonso F, Giraldo-Beltran P, Ramirez F (2010). Initial effects of fragmentation on the density of three Neotropical primate species in two lowland forests of Colombia. Endangered Species Research 13: 41-50.

Marsh C, Link A, King-Bailey G, Donati G (2016). Effects of fragment and vegetation structure on the population abundance of Ateles hybridus, Alouatta seniculus and Cebus albifrons in Magdalena Valley, Colombia. Folia Primatologica 87: 17-30.

Matsuda I, Otani Y, Bernard H, Wong A, Tuuga A (2016). Primate survey in a Bornean flooded forest: evaluation of best approach and best timing. Mammal Study 41: 101-106.

Medellín RA, Equihua M (1998). Mammal species richness and habitat use in rainforest and abandoned agricultural fields in Chiapas, Mexico. Journal of Applied Ecology 35: 13-23.

Méndez-Carvajal PG (2013). Population size, distribution and conservation status of howler monkeys (Aloutta coibensis trabeata) and spider monkeys (Ateles geoffroyi azuerensis) on the Azuero Peninsula, Panama. Primate Conservation 23: 3-16.

Nekaris KAI, Pambudi JAA, Susanto D, Ahmad RD, Nijman V (2014). Densities, distribution and detectability of a small nocturnal primate (Javan slow loris Nycticebus javanicus) in a montane rainforest. Endangered Species Research 24: 95-103.

Nijman V, Menken SBJ (2005). Assessment of census techniques for estimating density and biomass of gibbons (Primates: Hylobatidae). The Raffles Bulletin of Zoology 53: 169-179. 
Peres CA (1999). General guidelines for standardizing line-transect surveys of tropical forest primates. Neotropical Primates 7: 11-16.

Pinacho-Guendulain B, Ramos-Fernández G (2017). Influence of fruit availability on the fission-fusion dynamics of spider monkeys (Ateles geoffroyi). International Journal of Primatology 38: 466-484.

Plumptre AJ, Sterling EJ, Buckland ST (2013). Primate census and survey techniques. In Primate Ecology and Conservation: A Handbook of Techniques (Sterling EJ, Bynum N, Blaire ME, eds.), pp 10-26. Oxford, Oxford University Press.

R Core Team (2016). R: a language and environment for statistical computing. http://www.r-project.org/.

Ramos-Fernández G, Ayala-Orozco B (2003). Population size and habitat use of spider monkeys at Punta Laguna, Mexico. In Primates in Fragments Ecology and Conservation (Marsh LK, ed.), pp 191-209. New York, Klewer Academic/Plenum.

Ramos-Fernández G, Aureli F, Schaffner CM, Vick LG (in press). Ecología, comportamiento y conservación de los monos araña (Ateles geoffroyi): 20 años de estudio en Punta Laguna, México. In La Primatología en Latinoamérica 2 (Urbani B, Kowalewski M, Grasseto Teixeira da Cunha R, de la Torre S, Cortés-Ortiz L, eds.). Altos de Pipe, Instituto Venezolano de Investigaciones Científicas.

Ravetta AL, Ferrari SF (2009). Geographic distribution and population characteristics of the endangered white-fronted spider monkey (Ateles marginatus) on the lower Tapajós River in central Brazilian Amazonia. Primates 50: 261-268.

Rhodes JR, McAlpine CA, Zuur AF, Smith GM, Ieno EN (2009). GLMM applied on the spatial distribution of koalas in a fragmented landscape. In Mixed Effects Models and Extensions in Ecology with $R$ (Zuur AF, Ieno EN, Walker N, Saveliev AA, Smith GM, eds.), pp 469-492. New York, Springer.

Richards SA (2015). Likelihood and model selection. In Ecological Statistics: Contemporary Theory and Application (Fox G, Negrete-Yankelevich S, Sosa VJ, eds.), pp 58-78. Oxford, Oxford University Press.

Ripley B, Bates D, Hornik K, Gebhardt A, Firth D (2013). Package 'MASS'. https://cran.r-project.org/web/ packages/MASS/index.html (accessed June 26, 2017).

Rosenberger AL, Halenar L, Cooke SB, Hartwig WC (2008). Morphology and evolution of the spider monkey, genus Ateles. In Spider Monkeys - Behaviour, Ecology and Evolution of the Genus Ateles (Campbell CJ, ed.), pp 19-49. Cambridge, Cambridge University Press.

Ross C, Reeve N (2011). Survey and census methods: population distribution and density. In Field and Laboratory Methods in Primatology, ed 2. (Setchell JM, Curtis DJ, eds.), pp 111-132. Cambridge, Cambridge University Press.

Shimooka Y (2005). Sexual differences in ranging of Ateles belzebuth belzebuth at La Macarena, Colombia. International Journal of Primatology 26: 385-406.

Shimooka Y, Campbell CJ, Di Fiore A, Felton AM, Izawa K, Link A, Nishimura A, Ramos-Fernández G, Wallace RB (2008). Demography and group composition of Ateles. In Spider Monkeys - Behaviour, Ecology and Evolution of the Genus Ateles (Campbell CJ, ed.), pp 329-350. Cambridge, Cambridge University Press.

Shupe TE, Guthery FS, Beasom SS (1987). Use of helicopters to survey northern bobwhite populations on rangeland. Wildlife Society Bulletin 15: 458-462.

Struhsaker TT (1981). Census methods for estimating densities. In Techniques for the Study of Primate Population Ecology, pp 36-80. Washington, National Academy Press.

Symington MM (1990). Fission-fusion social organization in Ateles and Pan. International Journal of Primatology 11: 47-61.

Treves A (2001). Reproductive consequences of variation in the composition of howler monkey (Aloutta spp.) groups. Behavioral Ecology and Sociobiology 50: 61-71.

Vick LG (2008). Immaturity in spider monkeys: a risky business. In Spider Monkeys - Behaviour, Ecology and Evolution of the Genus Ateles (Campbell CJ, ed.), pp 288-328. Cambridge, Cambridge University Press.

Wallace RB (2001). Diurnal activity budgets of black spider monkey, Ateles chamek in southern Amazonian tropical forest. Neotropical Primates 9: 101-107.

Weghorst JA (2007). High population density of black-handed spider monkeys (Ateles geoffroyi) in Costa Rican lowland wet forest. Primates 48: 108-116. 